\title{
As "revelações" do melodrama, a Rede Globo e a construção de uma memória do regime militar $^{1}$
}

//I/I/I/I/I/I/I/ Mônica Almeida Kornis ${ }^{2}$

1. Versão modificada de trabalho com o mesmo título apresentado no Grupo de Trabalho Estudos de Televisão do XX Encontro da Compós (Associação Nacional dos Programas de Pós-Graduação em Comunicação), realizado na Universidade Federal do Rio Grande do Sul, em Porto Alegre, entre 14 e 17 de junho de 2011.

2. Pesquisadora do Centro de Pesquisa e Documentação de História Contemporânea do Brasil da Fundação Getulio Vargas e professora do Programa de Pós-Graduação em História, Política e Bens Culturais e da Escola Superior de Ciências Sociais da mesma instituição. Doutora em artes pela Escola de Comunicações e Artes da Universidade de São Paulo. E-mail: monica.kornis@fgv.br 
Resumo

O objetivo do presente texto é examinar os formatos e as estratégias narrativas utilizadas na configuração de uma memória da história do regime militar brasileiro pela Rede Globo, numa perspectiva que não pretende a busca por uma verdade histórica, mas sim a análise dos parâmetros definidos por uma matriz de natureza melodramática nessa reconstrução histórica. Na programação de ficção seriada e de docudrama, a Rede Globo demarca, assim, seu lugar de importante agente de construção de uma identidade nacional, na qual a narrativa histórica ocupa um lugar de destaque.

\section{Palavras-chave}

televisão e história, Rede Globo, memória e história, regime militar brasileiro

\section{Abstract}

The aim of this article is to analyse how the formats and the narratives strategies made by Rede Globo had built a memory of the Brazilian military regime. The purpose of the text is not to identify a historical truth, but to discuss the boundaries of the historical reconstruction in a melodramatic shape. In docudramas and in fictional series, Rede Globo assumes her role as an important agent in the construction of a national identity, in which the historical narrative holds a good position.

\section{Key-words}

television and history, Rede Globo, memory and history, Brazilian military regime 
A narrativa televisiva da história se realiza há quase três décadas na programação ficcional da Rede Globo - em programas de distintos formatos - e mais pontualmente em outras emissoras brasileiras. Adaptações de títulos importantes da literatura brasileira ambientados em diferentes momentos de nossa história foram realizadas e exibidas em telenovelas ao longo da década de 1970, mas foi a partir dos anos 1980 que a Rede Globo consolidou a tendência - sobretudo na programação de minisséries - , contemplando casos e personagens reais e ficcionais, desde os tempos coloniais. Trazer a história recente nacional para o horário das minisséries foi fruto dos debates realizados durante a curta duração da Casa de Criação Janete Clair (KORNIS, 2003, p. 78-79), formada em 1984 e em homenagem à dramaturga que, falecida no ano anterior, é até hoje considerada um dos maiores nomes da teledramaturgia da emissora. Nasceu ali, entre outros projetos e discussões, a ideia de produzir uma minissérie ambientada no governo Juscelino Kubitschek, identificado a partir da redemocratização do país, em 1985, como o contexto exemplar de democracia de nossa história republicana, associação construída até hoje - das campanhas eleitorais aos discursos presidenciais. Se em 1983 a emissora nada divulgou sobre as articulações que culminaram no ano seguinte no movimento das Diretas Já - e que contou com uma cobertura jornalística que identificou aquela manifestação política como espetáculo musical —, com a mudança de regime, em 1985, a Rede Globo começaria a "contar" a história recente do país. Nos anos 1990, passaria a abordar o regime militar 
(1964-1985) na produção ficcional e, nos anos 2000, no formato de docudrama, quando veio a tratar de casos reais ocorridos naquela conjuntura. Entretanto, já no ano seguinte à instalação da então chamada "Nova República”, a minissérie Anos dourados (1986) mencionava, no epílogo, o destino de alguns personagens ao longo da década de 1960. Em voz em off, referiu-se à radicalização política, à repressão e à clandestinidade ocorridas nos anos 1960, nas cenas finais da primeira exibição da minissérie.

Nessa perspectiva, a televisão seguia os passos iniciados pelo cinema, que, de maneira alegórica ou realista, tratara do período desde os anos 1960 - e até hoje, em mais de uma centena de títulos - , ao abordar questões que lhe eram contemporâneas, mesmo após o recrudescimento da censura imposta pelo regime a partir do final de 1968. Por outro lado, esse movimento expressava uma tendência já consolidada, se pensarmos sobre a força da relação "cinema e nação", um binômio que se impôs desde os primórdios do cinema narrativo clássico, nos anos 1910, e também em algumas cinematografias de ruptura com essa linguagem, a partir dos anos 1920. A dramatização da história é assim um fenômeno quase centenário, em particular no cinema industrial - com fatos e personagens reais ou ficcionais em meio a histórias de dramas individuais, biográficos ou não - , que privilegia acima de tudo a construção de uma verossimilhança no tratamento de diferentes temas, apesar das singularidades de cada uma das produções, o que justifica a importância de suas análises internas. Em relação ao período histórico em questão, personagens reais foram tratados de maneira distinta pelo cinema e pela televisão, apesar da forte presença de uma matriz melodramática na configuração de narrativas biográficas em ambos os domínios, como é o caso da história sobre Zuzu Angel, exibida tanto pelo filme de Sergio Rezende com esse mesmo título (2006) quanto pelo episódio sobre a vida da estilista exibido em Linha direta - justiça (2003).

Considerando a importância da televisão em todo o mundo como agente de construção de uma identidade nacional, na qual o passado histórico constitui-se como um importante elemento, a ideia do presente trabalho é examinar sobre quais formatos e no interior de que estratégias narrativas a Rede Globo atuou, a partir de 1985, enquanto construtora de uma memória televisiva sobre o regime militar, e com que parâmetros e limites, definidos a partir dos diferentes tratamentos narrativos e estéticos, isso foi feito. Pretende- 
se explicitar como ficções televisivas seriadas e dramatizações de casos reais sobre esse período de nossa história recente reafirmaram a força da relação televisão-identidade nacional e, em particular, a presença da Rede Globo como agente desse processo. A emissora sem dúvida modela uma história, e isso nos interessa investigar, não em busca de uma verdade histórica, mas pelo exame das estratégias discursivas de construção de memórias de uma história nacional. Foi somente com a redemocratização do país, num contexto de recomposição de forças políticas no poder, que a emissora ampliaria o espectro de seu olhar para a história nacional.

A ideia de nação com a qual trabalhamos baseia-se na noção de “comunidade imaginada" (ANDERSON, 1989, p. 14-15) e consideramos que a construção de uma memória histórica é um elemento vital para a criação de um sentimento de pertencimento nacional, e sobre a qual se define uma determinada identidade. Enquanto agente de construção de identidade nacional, a Rede Globo ocupou esse papel desde o início dos anos 1970, constituindo-se como importante peça do projeto de integração nacional definido pela política de segurança nacional preconizada pelo governo militar. Nesse processo, o ano de 1969 foi fundamental, porque nesse ano a emissora lançou o jornal diário da noite em rede nacional - o Jornal Nacional - e também definiu uma nova linha na programação ficcional de telenovelas, que passariam a contemplar em suas tramas aspectos da sociedade brasileira. A incorporação do elemento "história nacional" na programação das minisséries a partir de 1982 - e com uma temática cara à literatura e ao cinema nacional, como foi o caso do cangaço - veio a reforçar uma estratégia pedagógica que, em poucas palavras, pode ser identificada como "quem somos?" (KORNIS, 2007, p. 97-114). Até hoje, esse papel é desempenhado pela emissora, apesar das variações impostas pelos diferentes contextos históricos e pela diversidade da produção ficcional.

A circulação de uma memória da história em escala de massa, como é o caso da realizada pela grande parte da produção televisiva, merece ainda ser pensada numa outra dimensão. Recorremos aqui a algumas considerações de Beatriz Sarlo, que utilizou a expressão "história de grande circulação" na identificação da particularidade de um tipo de produção cultural ao gosto do mercado que, calcada na memória, se apresenta como uma história de sínteses, e não de dúvidas (SARLO, 2007, p. 9-22). Apesar de a autora referir-se nessa 
formulação ao caso específico de uma determinada produção editorial, acredita-se que essa noção possa ser bastante útil para pensarmos as características da história no cinema e na televisão enquanto "commodity" (SOBCHAK, 1996, p. 1-7). Do ponto de vista crítico, isso aponta, no nosso caso, para a importância de avançarmos para além das aparências expressas como sínteses pelo conteúdo dos filmes e dos programas de televisão e das referências exclusivas ao contexto de produção e exibição, na direção de uma análise das estratégias narrativas e estéticas. Nesse sentido, identificamos a necessidade de pensá-las nos moldes dentro dos quais buscam se adequar ao gosto do público, que há séculos se identifica, de maneira realista, com a moral escondida da virtude num espetáculo de heróis e vilões, cuja tensão dramática se resolve enquanto uma recomposição de uma ordem moral, num movimento definido nos moldes de uma estrutura melodramática (BROOKS, 1976; XAVIER, 2003, p. 129-141).

É no interior dessa matriz e dentro desses parâmetros que podemos examinar como a memória da história do regime militar é concebida pela Rede Globo, uma "história de grande circulação", consumida por uma população de cerca de 190 milhões de habitantes - 80\% deles, vivendo na zona urbana. O foco moral e pedagógico da história na ficção e a definição dos personagens ficcionais e reais a partir dessa concepção modelam de uma determinada maneira o passado histórico e, dessa forma, "revelam" ao público uma história nacional (KORNIS, 2001). Empenhadas no "parecer ser real” na reconstrução histórica, as minisséries e o docudrama que abordaram o regime militar trataram-no ainda de maneira individualizada. No caso do programa Linha direta em particular, há uma opção pelo tratamento biográfico, na reconstrução da história de personagens reais assassinados e vítimas da tortura nos anos 1970 e que se configurarão como "casos" de exceção - o que pode ser entendido também como individual, nesse sentido - , fruto de excessos cometidos em momento já de abertura política, como veremos mais adiante.

Em linhas gerais, as minisséries trataram o tema preferencialmente na perspectiva de trajetórias geracionais, numa tendência assim mais explícita na televisão do que no cinema. De uma maneira mais evidente em dois trabalhos de Gilberto Braga, isso se realizou em Anos rebeldes (1992) e secundariamente em Anos dourados (1986), minisséries cujos títulos por si só evocavam um retorno ao passado, numa reconstrução preferencial de seus aspectos compor- 
tamentais e políticos. A ideia de trajetória geracional também esteve presente em Hilda Furacão (1998), romance do mineiro Roberto Drummond, apesar de a adaptação de Gloria Perez ter como eixo narrativo o comportamento rebelde de Hilda e as tensões daí advindas. Em meio a conflitos pessoais e familiares, com foco na trajetória geracional, a referência ao contexto político na ficção como um elemento organizador do desenrolar da narrativa foi evidenciada pelos três títulos acima, mesmo que Anos dourados só fizesse referência aos anos 1960 no epílogo.

Alguns outros títulos remeteram-se à época, de forma menos vital na construção narrativa, mas devem ser mencionados. Dez anos depois de Hilda, a trajetória da geração dos anos 1970 foi tratada em Caros amigos (2008), de Maria Adelaide Amaral, a partir do reencontro de amigos - sem dúvida, de uma geração também ao final dos anos 1980, mais precisamente em 1989, após a queda do Muro de Berlim. A narrativa não privilegiava flashbacks, tendo como foco o reencontro propriamente dito, patrocinado por um dos membros do grupo, gravemente doente. Há apenas referências pontuais ao passado, com a função de caracterizar alguns personagens que eram ajudados por esse amigo rico, prestes a morrer: um deles era uma jovem que, presa em 1974 e torturada no DOICodi (Destacamento de Operações de Informações - Centro de Operações de Defesa Interna), dedicava-se ao estudo de astrologia e budismo para superar traumas dos "anos de chumbo", e o outro era um escritor que abordava em seus trabalhos aspectos sombrios e desconhecidos da ditadura militar. Não havia um atrelamento à questão da política como foco, posto que o eixo narrativo referia-se a tensões de natureza pessoal e existencial em torno do reencontro desses amigos. Embora cada personagem fosse definido por um conjunto de referências ao passado, o posicionamento dessas figuras não se pautou pela narrativa enquanto repertório de identificação de cada uma delas com o momento no qual haviam se conhecido. Da mesma forma, a minissérie Decadência (1995), de autoria de Dias Gomes, abordou dois momentos do regime militar, apesar de o foco ser o retrato do país entre os anos de 1984 - a partir da mobilização nacional em torno das eleições diretas para a Presidência da República - e 1992. Há um breve recuo narrativo para 1970, ano em que se iniciava a história de uma família bastante rica e influente, que vivia pacificamente. Não há uma referência 
de natureza política a esse momento, mas é possível pensarmos alegoricamente numa perspectiva de estabilidade para uma família aristocrática naqueles tempos de ditadura, nos quais o cenário privilegiado era uma bela mansão, em que o cotidiano transcorria na mais absoluta paz e com alegria. A narrativa propriamente dita iniciava-se em 1984, quando há uma ruptura com o espaço doméstico familiar, que se funde com os momentos finais do governo militar, via mobilização pelas eleições diretas. No palanque, junto de Tancredo Neves, encontrava-se o jurista liberal Albano Tavares Branco, patriarca da família; pouco tempo depois, a inquieta neta Carla se rebelaria contra a eleição indireta para a Presidência da República. O repertório de cada um dos personagens se construiria, a partir desse momento, já na chamada "Nova República”, em meio aos embates de uma família em crise, em sintonia com um país que igualmente vivia um processo de escândalos e no qual a luta pela ética dominava a cena narrativa (KORNIS, 2006, p. 103144). Mais pontuais ainda foram as referências na microssérie Luna caliente (1999), a partir de romance escrito em 1983, ambientado na Argentina em 1974, com adaptação de Giba Assis Brasil, Carlos Gerbase e Jorge Furtado, também diretor. Ambientada em 1970 no interior do Rio Grande do Sul, seu foco não foi de natureza política - só havia uma única referência, explícita no fato de o personagem central ter retornado de um exílio na França em data não muito definida - , e sim amorosa, pois tratava da intensa paixão desse homem pela filha de um amigo, uma jovem de 15 anos de idade, e sua condenação pelo desaparecimento desse amigo.

$\mathrm{Na}$ linha do docudrama, o popular programa Linha direta, em seu segmento Justiça, exibido entre os anos de 2003 e 2007, tematizou casos reais ocorridos durante a ditadura militar. Foram cinco casos, o que demonstra ter sido esse o programa da Rede Globo que mais abordou aquele período histórico. Vale mencionar que os casos políticos ali tratados foram quase que exclusivamente voltados para aquele contexto. As biografias de Zuzu Angel, Vladimir Herzog, frei Tito e cabo Anselmo e o episódio da bomba do Riocentro formam o eixo dramático de construção de uma memória do regime militar, cujo formato tem como objetivo final o "fazer justiça", expressão já contida no próprio título desse segmento do programa.

Mantida a cronologia de exibição dos programas, uma breve análise de cada uma das três minisséries e dos referidos casos em Linha 
direta - justiça pretende discutir como cada um dos títulos definiu, em sua singularidade, a construção de uma memória da história do regime militar, na relação com seus contextos de produção.

\section{Os anos 1960 como epílogo de uma época "dourada"}

Anos dourados (1986), de Gilberto Braga, primeira minissérie ambientada no passado nacional recente, em meados dos anos 1950, referiu-se aos anos 1960, no epílogo, em voz em off. Com uma narrativa estruturada sobre uma trajetória geracional em meio a uma polarização entre pais e filhos, centrada num conjunto de referências não só comportamentais mas também de natureza política em relação à vida brasileira durante o governo Juscelino Kubitschek, tinha como eixo central o confronto entre valores hipócritas e autênticos, binômio que se manifestava como um divisor de águas entre os personagens e as situações por eles vividas. Anos dourados tratava de um processo de transição de uma sociedade arraigada em valores conservadores - da política ao comportamento afetivo dos jovens e dos adultos - para uma mais aberta, identificada na narrativa como moderna e democrática. Nesse sentido, realizava a alegoria de um momento histórico que se apresentava como novo, posto que democrático - a chamada "Nova República", instaurada em 1985 -, contrapondo uma sociedade retrógada, patriarcal, clientelística a outra apresentada como nova e verdadeira, identificada com a perspectiva juscelinista revivida como um momento de otimismo, em 1986, após 21 anos de regime militar (KORNIS, 2003, p. 75-127).

Nessa perspectiva, a questão comportamental é dominante e organiza a trama, muito embora fatos políticos atuem também enquanto definição do repertório dos personagens adultos, marcando o posicionamento deles diante da dicotomia colocada pela oposição entre valores autênticos e hipócritas. É importante ressaltar que a estrutura narrativa da minissérie situa o lugar dos personagens em cada uma das conjunturas, isto é, ao longo dos anos 1950 e, mais adiante, ao final dos anos 1960. Na última sequência da minissérie, enquanto epílogo, os jovens dos anos 1950 aparecem adultos. O casal que lutara contra os valores conservadores, movido por valores autênticos, é apresentado como realizado no matrimônio, em meio a seus filhos, além de terem profissões que podem ser identifica- 
das como dignas e humanas - ele, veterinário, e ela, pedagoga espécie de atestado de vitória de uma geração moralmente mais autêntica.

Interessa-nos tratar aqui sobre as duas únicas menções em off que politizam a realidade brasileira depois de 1964. Apesar de pontual, a informação organiza os campos da direita e da esquerda de uma conjuntura politicamente polarizada: um dos jovens nos anos 1950, Claudionor, havia se tornado um general de direita, lotado no Centro de Informações do Exército, e Pedrinho, irmão bem mais novo da heroína Lurdinha, era estudante de arquitetura no momento em que foi preso durante uma das manifestações estudantis de 1968, e estava desaparecido. Quem eram esses personagens nos anos 1950? Claudionor era o personagem mais gordo, desajeitado, que não fazia sucesso com as jovens, mas era estimado pelos colegas, mesmo quando optou pela carreira militar e deixou o Rio de Janeiro. Já Pedrinho era um personagem secundário, muito mais jovem que todo o grupo de adolescentes com os quais convivia. Criança reprimida pelos pais excessivamente conservadores, Pedrinho observava tudo, sem nada dizer. Ouvia os comentários preconceituosos de seus pais e era um cúmplice discreto da irmã. Sua primeira fala foi em confessionário, ao contar para o padre ter pecado contra a castidade com um menino. Fiel à composição de um retrato comportamental de época, marca do estilo de teledramaturgia de Gilberto Braga, a questão da sexualidade é vital na minissérie, e Pedrinho é repreendido pela mãe por brincadeiras de médico com a prima, num momento da narrativa na qual se intensifica a tensão entre atração sexual e educação repressiva, cujo foco é o casal de adolescentes Lurdinha-Marcos. É Pedrinho, criança desprovida de argumentos, quem estende o braço para ser punido pela mãe, numa cena marcada pelo tom grave dado pelo fundo musical. Pouco antes de a trama atingir seu clímax, com a revelação de que o pai se suicidará por ter sido reconhecido como o assassino de sua própria amante, a mãe de Pedrinho lhe ensinava sobre antônimos, cuja polarização pode ser entendida como expressão de uma pedagogia que reafirma o universo de inocentes e culpados que se desvendará a seguir: ela diz a palavra "inocente" (é possível pensar numa alusão ao marido, que revelará a seguir sua face de culpado), e ele diz "culpado" (como que reconhecendo os erros da hipocrisia que serão a seguir revelados). Pedrinho era estudante no Colégio Militar por imposição da mãe, mas ele não se rebelava contra isso. No desfe- 
cho da trama, a mãe o levava à escola, e ele pacientemente a beijava, num momento de intenso conflito psíquico pelas condições da morte do marido, em meio a um esforço para "manter as aparências".

O personagem engajado politicamente no final dos anos 1960 sofreu as imposições de uma sociedade conservadora da década anterior. Pouco falava quando criança - apesar de discretamente se posicionar favorável à irmã quando ela se rebelava contra valores hipócritas - , e foi esse o primeiro personagem cuja militância contra a ditadura se expressou claramente na ficção televisiva, tendo sido ainda um desaparecido político. Não há ainda aqui um tratamento heróico do personagem, como veremos em outras narrativas ficcionais, mas essa descrição pode ser percebida como um primeiro momento - mesmo que tímido - na abordagem do tema pela televisão no início da chamada "Nova República". Configura-se como um olhar crítico infantil dos anos 1950, que viria a explodir na opção política radical assumida nos anos 1960.

\section{A geração dos anos 1960 em tempos "rebeldes"}

A minissérie Anos rebeldes (1992), escrita por Gilberto Braga e Ricardo Linhares, tinha como foco a trajetória de um grupo de colegas de escola de ensino médio entre os anos 1964 e 1979. A trama central é a conflituosa relação amorosa entre João Alfredo e Maria Lúcia, em função de suas diferentes personalidades, vivências e visões de mundo. Ele é idealista, e sua preocupação com a justiça social o conduzirá à militância política dos anos 1960 até os anos 1980. Ligada à família e voltada para seu universo pessoal, Maria Lúcia teme as adversidades que acompanham a atividade política do pai, jornalista, e posteriormente transferirá esse receio para João, cujo comportamento põe em risco seu desejo de uma vida estável. A tensão aqui expressa entre individualismo e engajamento político define o conflito central da narrativa, e a pontuação política, o eixo fundamental de polarização entre o casal (KORNIS, 2001). Sem necessariamente expressar um rigor cronológico na composição do painel de época, mas sem dúvida em consonância com uma estratégia realista de verossimilhança, numa chave até então inédita na ficção seriada televisiva, imagens de arquivo foram inseridas ao longo de toda a narrativa da minissérie, com destaque para referências 
de ordem comportamental e cultural.

No interior da polaridade vivida pelo jovem casal, definida nas primeiras cenas da minissérie, ficção e história na ficção se organizam em meio a uma correspondência das idas e vindas do casal com o espaço da política narrado na ficção, exceto no momento da radicalização política de João, no qual clandestinidade e perseguição policial assumem o tom de filme de ação e de aventura. A estreita relação entre a trama romântica/geracional e a vida política nacional revela uma particularidade no tratamento dos fatos históricos que vão do golpe militar à anistia e à reorganização das forças de oposição ao regime. História na ficção e ficção propriamente dita são mutuamente construídas por intermédio de uma articulação fundada nas tensões entre um conjunto de jovens da geração dos anos 1960, cada qual com um repertório bastante definido do ponto de vista político e comportamental.

Os conflitos dramáticos vividos pelos personagens principais e secundários expressam genericamente algumas das grandes tendências, naquele momento, da luta política contra o regime, mas o desenlace da trama não aponta para um único caminho - ao contrário, abre um impasse, que é a impossibilidade de realização do casal João e Maria Lúcia, isto é, da resolução do conflito entre engajamento político e individualismo, que alavanca todo o desenrolar da trama. Impasses e opções dadas historicamente são elementos fundamentais da narrativa, muito embora não haja a explicitação direta do inimigo que alavanca dramaticamente a trama. $\mathrm{O}$ conflito político reside na luta exclusiva de elementos radicalizados das classes médias e altas contra um governo, sem identidade, sem nomes - há uma única menção ao presidente Ernesto Geisel, no ano de 1974 - , na qual as decisões políticas, tal como o Ato Institucional $\mathrm{n}^{\circ} 5$ (AI-5), não possuem autores; são como que uma ordem que emana de uma autoridade. O processo de radicalização é individualizado, sem que sejam explicitadas as propostas do movimento. A diversidade de tendências de esquerda também é reduzida à dicotomia entre o Partido Comunista - conciliador e com um militante adulto - e a luta armada - radical e jovem, apesar da adesão do pai de um dos jovens a essa vertente.

O exame do personagem principal da trama é particularmente importante como confirmação da centralidade da questão da militância política na narrativa. As primeiras cenas da minissérie an- 
tecipam a radicalização política de João, ao mostrá-lo em assalto a um banco em 1970, seguida pela relação tensa vivida com Maria Lúcia, cuja posição é contrária à opção do namorado pela luta armada. Mesmo apresentado enquanto tal, João será ao longo de toda a narrativa o jovem inquieto e bem-intencionado, defensor da justiça social, movido por atitudes dignas e humanas, que se chocam frontalmente com o individualismo de Maria Lúcia. De boa índole, numa busca desenfreada por justiça e tendo feito a opção pela luta armada contra o governo, João transforma-se no herói da trama, em contraste com sua aparência frágil, porém firme. Se a paixão por Maria Lúcia e a tensão da relação do casal são elementos fundamentais na construção narrativa, ela, no entanto, não é a heroína feminina, mas sim a personagem Heloísa. Ao contrário de João, rapaz de classe média, ela é filha de um homem rico e poderoso, tratada como uma burguesa excêntrica, como que de caráter naturalmente transgressivo e corajoso, que migra das festas da alta sociedade para a luta armada. É a única personagem torturada - em torno dela reside uma breve menção a essa prática na minissérie - e acaba sendo morta em blitz policial. João e Heloísa são sem dúvida personagens heróicos e positivos - cada um inquieto a sua maneira em conflito com o status quo, mesmo que por caminhos distintos. Esse dado é importante na configuração de um lugar de destaque na narrativa para uma opção política radical.

O lugar da política na trama é decisivo, contudo, ao demarcar a cisão entre os jovens colegas de colégio em função da repressão que se sucede à missa de sétimo dia de Edson Luís, estudante morto por policiais no restaurante do Calabouço em março de 1968. Sua morte é o único fato político que imprime uma ruptura na narrativa, constituindo-se como marco decisivo no processo de radicalização política de João, que aqui se inicia pelo isolamento progressivo de seu círculo próximo de amigos, até a decretação do Ato Institucional $n^{\circ}$. Se em 1964 todos os jovens eram amigos movidos pelo mesmo ideal de justiça social, tendo à frente João, há uma mudança com a decretação do AI-5, em dezembro de 1968. Um dos mais próximos amigos de João, Edgar, é apresentado como um fraco diante da escalada de repressão, e entra em disputa cerrada com João pelo amor de Maria Lúcia, com quem acaba se casando, além de se tornar um próspero proprietário de editora. Enquanto outro amigo, Galeno, reafirma seu interesse pela área cultural, torna-se 
hippie e cede aos apelos da indústria cultural, escrevendo ficção para a televisão, Valdir, o mais humilde deles e filho do porteiro do prédio de João, trai os amigos e torna-se um informante do pai de Heloísa, por priorizar a ascensão social a qualquer custo.

Esse painel geracional bastante diversificado e tratado de forma nuançada pelo olhar agudo de Gilberto Braga - cujo traço estilístico de crítica social e de costumes, típico de sua dramaturgia, se realiza plenamente em Anos dourados e em Anos rebeldes, na condição de um retrato de época - foi exibido simultaneamente à ampla mobilização dos jovens caras-pintadas, depois do impeachment do ex-presidente Collor. O estabelecimento de uma correspondência entre esses fatos foi amplificado pela mídia impressa não só enquanto um revival dos anos 1960 nos cadernos de cultura e moda mas também na referência a contextos de forte presença jovem no âmbito da política, mesmo que no primeiro caso a luta tivesse como foco a transformação social e, no segundo momento, se constituísse no âmbito de uma discussão sobre a ética na política.

\section{A narrativa mágica de um amor impossivel em tempos de transição}

A questão política não se constituiu como o foco da minissérie Hilda Furacão (1998), adaptação de Glória Perez do romance de Roberto Drummond, ambientada entre os anos de 1959 e de 1964 , com um breve epílogo no ano de 1968. A trama gira em torno da rebeldia e do inconformismo da personagem Hilda contra uma sociedade moralista e hipócrita, na qual se inscreve o amor proibido por um aspirante a frei dominicano. Apesar de não ter a centralidade que possui no romance de Drummond, a questão geracional também se faz presente na minissérie no tratamento da história de três amigos de infância que deixam juntos o interior mineiro rumo à capital, Belo Horizonte. Um desses jovens é Malthus, que viverá uma paixão por Hilda, desde o momento em que a conhece, na tentativa de demovê-la da prostituição. Numa narrativa que pode ser identificada como mágica pelas previsões, por uma cartomante, de uma grande paixão que mobilizaria Hilda, a rebeldia misteriosa da personagem, seguida pela opção pela prostituição, e os dilemas do bem-intencionado Malthus, em crise por uma vocação religiosa impossível de se realizar pela paixão que o atormenta, opõem-se a 
uma sociedade conservadora e hipócrita, marcada pelo moralismo e pelo temor de um avanço comunista no início dos anos 1960. Não há em Hilda Furacão uma sociedade em modernização como em Anos dourados. O lugar do pecado pode também ser o lugar onde se encontra a virtude, se pensarmos no conflito interno vivido por Malthus, cujo desejo é viver com Hilda e ter a revelação das razões de sua opção de vida. A data marcada para o momento de saída de Belo Horizonte rumo ao Rio de Janeiro é, alegoricamente, a data de eclosão do golpe militar de 1964, quando o casal acabaria por não conseguir se encontrar. Momento liberador que na realidade não acontece e que se opõe ao fato histórico que se inicia naquela data - o golpe militar que se consumará a partir da saída de tropas de Minas Gerais para o Rio - , num sentido oposto ao de uma liberação, posto que aponta para o que será o fechamento do regime. Apesar de Malthus não ser caracterizado como crítico à ditadura, há uma alusão a isso pela sua identificação com uma vertente progressista da Igreja, manifesta pelo desejo em trabalhar com dom Hélder Câmara no Rio de Janeiro ou no Recife, estratégia que amplia o seu repertório enquanto um homem bom, já que é próximo aos pobres. Há uma correspondência entre a derrota da esperança e da felicidade, pelo desencontro do casal, e a derrota de uma revolução, sugerida pela morte de um anarquista e de um comunista em meio aos distúrbios na capital mineira - o que, com o rebuliço nas ruas, impede o encontro de Hilda e Malthus.

A narração em off sobre o destino dos personagens nas cenas finais da narrativa, seguida por imagens de manifestação contra a ditadura no ano de 1968, no Rio de Janeiro, e de confronto com a polícia, nas quais se encontra Malthus, arma um novo momento de esperança e renovação, que virá também a se colocar enquanto incerteza. Numa estratégia alegórica, a esperança vivida nesse momento político de luta contra o regime - há cartazes de "abaixo a ditadura" - corresponde à esperança de Malthus, que, naquele contexto, encontrava nas ruas do centro do Rio, em meio às manifestações, um sapato vermelho, que retomava a previsão da cartomante de que Hilda se apaixonaria pelo homem que encontrasse esse objeto - sem dúvida, fetiche - nas ruas, fato que levara ao encontro de Malthus e Hilda. Instala-se uma esperança que pode se dissipar em dúvida, pois, se a narrativa não é conclusiva em termos do futuro da relação entre Malthus e Hilda, o espaço externo 
à diegese é negativo, considerando que as manifestações daquele ano apontavam para uma revolta crescente contra o governo, que em dezembro de 1968 decretaria o $\mathrm{AI}_{-5}$, marco fundamental no fechamento do regime.

\section{A "verdade" e a "justiça" na reconstrução de casos reais}

Após uma primeira edição com poucos meses de duração no ano de 1990, Linha direta voltou a ser exibido em 1999, com o mesmo objetivo de reconstituição de crimes de assassinato, estupro e sequestro de desconhecidos, que, com apelo sensacionalista, mesclava jornalismo e dramaturgia. Em busca de culpados, com o objetivo de fazer justiça e de restabelecer a ordem, num movimento tipicamente melodramático, o programa pretendia não só elevar os índices de audiência na concorrência com o Programa do Ratinho (SBT) mas também apresentar-se como prestador de um serviço de utilidade pública. Com direção geral de Milton Abirached, a partir do ano de 2000 , casos envolvendo figuras públicas foram também tratados pelo programa, tal como o assassinato do tesoureiro da campanha do ex-presidente Collor, Paulo César Farias, e de sua namorada, Suzana Marcolino, o que apontava para uma tendência de dramatização de histórias que dialogavam diretamente com fatos políticos.

A partir de 2003, com as mesmas características do formato, iniciava-se dentro do programa a série Linha direta - justiça, que, exibida até 2007 , trouxe cerca de 40 histórias de grande impacto no passado, tais como os famosos casos de Ladeira do Sacopã, Aida Curi e Dana de Tefé nos anos 1950, no Rio de Janeiro, até os desaparecimentos dos jovens Carlinhos e Ana Lídia. Além dos crimes passionais, crimes de natureza política também foram tematizados pela referida série, que privilegiou nessa vertente o período do regime militar.

A organização da narrativa no programa apoia-se na narração dos casos em off e em alguns momentos também pelo jornalista Domingos Meirelles, com alternância de depoimentos de familiares e amigos, de advogados e de juristas, preferencialmente de personalidades com alguma visibilidade, todos atuando como instrumentos estratégicos de autenticação de uma "verdade". A dramatização das histórias particulares se faz no mesmo formato geral do programa. Narração tensa, tom realista, edição rápida, permanente sonoridade 
3. Jornal do Brasil, 31 de dezembro de 2003 , e entrevista com Milton Abirached realizada no Rio de Janeiro, em 7 de novembro de 2011. de mistério e suspense, com entrevistas com fundos em tons de vermelho bem saturado, sem a luminosidade típica da ficção seriada, em meio à simulação de fatos reais, que conta com a presença de atores, o que confere verossimilhança ao desenrolar do caso. Milton Abirached afirma que foi essa a intenção de toda a programação de Linha direta: utilizava uma câmara na mão por vezes invasiva sobre os próprios atores, como se fizesse um filme de ação, com a edição de tomadas em plano-sequência, tentando colocar o espectador dentro da cena, na busca de um programa "verdade", intercalando depoimentos e cenas de simulação, com a condução de Meirelles em tom sereno, no esforço de amenizar o "mundo cão" expresso na reconstituição dos casos³.

Em relação aos casos de nosso interesse, a referência ao contexto histórico realiza-se exatamente na medida da relação com o personagem em foco. Uma vez consumadas as mortes, a narrativa volta-se sempre para a dimensão jurídica, com vistas à apuração das responsabilidades no momento em que o caso tende a ser esclarecido e, ao final, é a fala de uma autoridade de governo e/ou parente da vítima que, juntamente com Meirelles, dá a palavra final sobre a resolução do caso. A "justiça” se faz assim pela apuração dos fatos pela ação jurídica revelada no programa, somada à "justiça" do próprio Linha direta, que fecha a narrativa do docudrama. Esse movimento, afinado com a matriz melodramática de apuração dos fatos para que se chegue à moral e à verdade, tende a se fazer em dois níveis: na referência ao processo jurídico e na construção do caso pelo docudrama, fiel às leis do formato do programa, que, nesses casos, assim constrói a memória dessas histórias, quase todas elas de natureza biográfica.

A história narrada tem aqui explicitamente a justiça como princípio condutor. Mesmo que ela não se realize plenamente, como em alguns casos, há uma dimensão moral cujo foco é o reconhecimento dos culpados e o restabelecimento da ordem. Uma referência a Sarlo é aqui importante para que se retome a dimensão de sua noção de "história de grande circulação", na busca por sínteses, e não por questões, exames e dúvidas. A síntese em Linha direta - justiça é bastante clara, como se pode apreender, e a individualização de casos de mortes e atentados, na condição de dramas individuais "resolvidos" pelo Poder Judiciário, estabelece os limites da construção da memória de uma prática de um regime de exceção. Considerando o melodrama como o formato que conforma essas narrativas, a vitória do bem e da moral é a apuração e a resolução 
do caso pela justiça tanto na vida real quanto na dimensão dada pelo programa, que também faz justiça, mesmo que em processos arquivados. Dos cinco casos exibidos, escolhidos por Abirached por se constituírem como "histórias que rendem" ${ }^{4}$, quatro consistem em narrativas biográficas dramatizadas.

Os casos de Zuzu Angel, Vladimir Herzog e frei Tito, exibidos pelo programa em 2003, 2004 e 2006 respectivamente - personagens reais assassinados ou levados ao suicídio pelo regime de força imposto pelo governo militar - , possuem características singulares, de acordo com suas histórias pessoais, transformadas em histórias heróicas na narrativa dos fatos. Há em todos eles uma valorização da virtude desses personagens, preferencialmente destacada pelos familiares e amigos próximos; narrativas cujo desfecho apela para essa dimensão pessoal, com viés evidentemente emocional, pela perda de uma pessoa de boas intenções. A abertura dos três programas se inicia com a apresentação do personagem central na situação que antecede a sua morte, demarcando seu lugar enquanto vítima de algo de que só teremos conhecimento depois. A dimensão trágica já é imediatamente dada. Zuzu Angel era a "mãe coragem" que lutava cegamente para localizar o corpo do filho, um militante político torturado e morto, até ser ela própria morta cinco anos depois, vítima de misterioso acidente automobilístico, mais tarde confirmado como sendo de natureza política5. Vladimir Herzog era o jornalista judeu imigrante que foi morto na prisão no mesmo dia em que fora chamado para depor sobre suas relações com o Partido Comunista. Frei Tito foi o padre que, após ter sido preso e torturado, exilou-se na França, onde foi o responsável pelas primeiras denúncias sobre as atrocidades do regime no exterior e onde se suicidou. Todas as mortes acontecem num momento de abertura política, durante o governo Ernesto Geisel - Zuzu, em 1976; Herzog, em 1975; e Tito, em 1974 - , assim como o episódio da bomba do Riocentro (1980) ocorre durante o regime de distensão preconizado pelo presidente Figueiredo. Podemos pensar que eram “exceções” e, portanto, anomalias, já que aconteceram durante um momento de abertura, sendo suprimida a memória de vários outros assassinatos, desaparecimentos e prisões ocorridos entre os anos de 1969 e 1973, como aliás fora o caso do próprio Stuart, filho de Zuzu Angel.

Outra narrativa biográfica foi exibida pelo programa, desta vez sobre o cabo Anselmo, um aliado de João Goulart e de Leonel
4. Entrevista realizada com Milton Abirached. Rio de Janeiro, 7 de novembro de 2011 .

5. Segundo Abirached, ele se sentira desafiado pela conhecida feminista Rose Marie Muraro, que, em depoimento ao programa sobre o caso do assassinato de Ângela Diniz, havia lançado a provocação de que não havia interesse em falar do assassinato de Zuzu Angel. O diretor afirmou ter levado a proposta à direção da emissora, que não se opôs ao tema. Entrevista realizada no Rio de Janeiro, 7 de novembro de 2011. 
Brizola, que foi uma das lideranças da revolta dos sargentos pouco antes do golpe de março de 1964, mas que se tornou um informante dos militares no início dos anos 1970. Dentro do mesmo formato, e tratando o caso igualmente como uma exceção, o lugar do personagem investigado pelo programa se inverte: não se trata agora de mais uma vítima do regime, mas de um traidor - na condição de um vilão - que se alia à repressão. Nessa mesma condição, o programa tematizou em 2005 o caso da bomba do Riocentro, fato ocorrido em 30 de abril de 1981, isto é, mais uma vez durante a abertura política, com o foco no grupo de militares que pretendia explodir o local em que haveria um grande show com nomes de sucesso da música popular brasileira, na véspera do Dia do Trabalho. Todo o processo de tensão no interior das Forças Armadas é detalhadamente tratado com depoimentos de autoridades e também com imagens de época, e o desfecho aponta para a anistia recebida pelos responsáveis pelo plano e para o fato de o inquérito ter sido arquivado. O programa arrola ainda outros casos de exceção - tal como atentados a bomba, entre os quais o que ocorreu na sede da Ordem dos Advogados do Brasil e que matou a funcionária Lyda Monteiro - , como que ampliando de forma tensionada o contexto do próprio caso Riocentro (KORNIS, 2011).

\section{Olhares sobre um passado "rebelde" em tempos democráticos}

As minisséries tratadas e o docudrama Linha direta - justiça podem ser identificados como narrativas de construção de uma memória sobre o regime militar brasileiro, a partir da redemocratização do país, num processo que chegou mesmo à programação das telenovelas, tais como em Mandala (1986) e Senhora do destino (2003). Além de reforçar um lugar de agente de construção de uma identidade nacional - cujo foco na reconstrução histórica é um elemento importante na programação seriada ficcional - , a Rede Globo passa a limpo um período histórico no qual as ligações com o regime lhe renderam severas críticas. Esse processo se constrói e se atualiza ao longo do tempo de diferentes maneiras, como confirma, a título de exemplo, a presença do então ministro da Defesa do governo Lula, José Viegas, no caso Zuzu Angel em Linha direta - justiça. Além de a montagem de seu depoimento atuar como pontuação de momentos da história do país desde os anos 1960, 
ele cumpre a função de garantir que o ano de 2003 era um momento novo nas Forças Armadas. Era possivelmente a confirmação de que o país mudara, considerando que as Forças Armadas eram democráticas, justamente no ano de posse de um operário na Presidência da República. Por outro lado, a presença de uma dimensão moral nos programas molda a construção desse período da história nacional, e não importa se os personagens e os casos são reais ou ficcionais. Em cada um dos títulos, há uma narrativa que, entre mortos e culpados, heróis e vítimas, fala de uma determinada maneira sobre esses personagens e casos de nossa história recente, sejam eles ficcionais, sejam eles reais. Ambos os formatos mobilizam afeto e emoção, ao gosto do espetáculo televisivo, tratados como dramas familiares e individuais.

No caso das minisséries, a construção de uma memória da história recente implicou narrativas dramáticas focadas na figura de jovens militantes, preferencialmente ligados à luta armada, opção que propiciou um relato heróico desses personagens, cuja atuação moralmente positiva se realizava enquanto defesa de ideais humanitários.

O segmento Justiça do programa Linha direta conferiu à biografia um lugar de destaque, com foco na atuação do personagem contrário ao regime, tratado como de exceção pela menção a agentes da repressão e órgãos de tortura, em meio a um sofrimento que extrapola o dele próprio, e se realizava, sobretudo, a partir das reações familiares pós-assassinatos e suicídios. Mesmo no caso de um traidor, e também no tratamento de um episódio que envolveu militares contra a abertura do próprio regime. O crivo da justiça é explícito e se realiza duplamente no formato do programa: na vida real, pela atuação da Justiça, e na própria construção documental/dramatizada, que se ergue como uma nova "camada" de justiça pela voz do jornalista âncora e por depoimentos de familiares e/ou autoridades de governo, autenticadores de uma verdade. O foco não recai sobre os conflitos políticos ou sobre a luta contra o regime imposto em 1964- a perspectiva é de síntese - ; nem são os jovens nem as ações armadas que alavancam esse processo, conforme expresso pelas minisséries.

Se a trajetória geracional moldou a reconstrução histórica do período em seus matizes comportamentais e políticos, e por vezes culturais, o foco no desvendamento de crimes e de ações armadas pela repressão confere à política e à justiça um lugar de destaque, num movimento que converge, em ambos os formatos, para uma reconstrução melodramática do passado. 
Referências

ANDERSON, B. Nação e consciência nacional.

São Paulo: Ática, 1989.

BROOKS, P. The melodramatic imagination: Balzac, Henry James and the mode of excess. New Haven: The University of Yale Press, 1976.

KORNIS, M. A. Uma história do Brasil recente nas minisséries da Rede Globo. Tese (doutorado). São Paulo: Escola de Comunicações e Artes da Universidade de São Paulo, 2001. "Ficção televisiva e identidade nacional: o caso da Rede Globo". In: CAPELATO, M. H.; MORETTIN, E.; NAPOLITANO, M.; SALIBA, E. T. (Org.).

História e cinema: dimensões históricas do audiovisual. São Paulo: Alameda, 2007.

. "Ficção televisiva e identidade nacional: Anos Dourados e a retomada da democracia”. In: ABREU, A. A.; KORNIS, M. A.; WELTMAN, F. L. Mídia e política no Brasil: jornalismo e ficção. Rio de Janeiro: FGV Editora, 2003. . "A Rede Globo e a construção da história política brasileira: o processo de retomada democrática em Decadência”. In: ABREU, A. A. de (Org.). A democratização no Brasil: atores e contextos. Rio de Janeiro: Faperj e FGV, 2006. "Linha Direta - Justiça e a reconstrução do regime militar brasileiro, ou quando o 'fazer justiça' cria uma memória da história”. In: BORGES, G.; PUCCI JR., R. L.; SELIGMAN, F. (Org.). Televisão: formas audiovisuais de ficção e de documentário. Faro; São Paulo: CIAC/ Universidade do Algarve e Socine, 2011. Disponível em: $<$ http://www.ciac.pt/publications.php?i=7>.

SARLO, B. Tempo passado: cultura da memória e guinada subjetiva. São Paulo; Belo Horizonte: Companhia das Letras e Editora da UFMG, 2007.

SOBCHAK, V. (Ed.). The persistence of history: cinema, television and the modern event. New York; London: Routledge, 1996.

XAVIER, I. O olhar e a cena: melodrama, Hollywood, cinema novo, Nelson Rodrigues. São Paulo: Cosac \& Naify, 2003. 